\title{
Fate of GAP-43 in Ascending Spinal Axons of DRG Neurons after Peripheral Nerve Injury: Delayed Accumulation and Correlation with Regenerative Potential
}

\author{
David J. Schreyer ${ }^{a}$ and J. H. Pate Skene \\ Department of Neurobiology, Stanford University School of Medicine, Stanford, California 94305-5401
}

Proteins characteristic of growing axons often fail to be induced or transported along axons that have been interrupted far from their cell bodies in the adult mammalian CNS. Here, we inquire whether long axons in the mammalian CNS can support efficient axonal transport and deposition of one such protein, GAP-43, when the protein is induced in neuron cell bodies. We have used immunocytochemistry to follow the fate of GAP-43 in dorsal column axons ascending the rat spinal cord from dorsal root ganglion (DRG) neurons, after synthesis of the protein is induced in these cells by peripheral nerve injury. Sciatic nerve lesions do lead to an accumulation of GAP-43 in dorsal column axons derived from the lumbar DRG. However, in distal segments of these CNS axons, accumulation of GAP-43 is apparent only after a delay of 1-2 weeks, in contrast to its rapid accumulation in axon segments within the PNS environment, suggesting that deposition and stabilization of GAP- 43 can be limited by local, posttranslational regulation. GAP-43 immunoreactivity subsides to control levels within 8 weeks after crush lesions that permit peripheral axon regeneration, but remains robust 8 weeks after resection lesions that prevent peripheral regeneration. Accumulation of GAP-43 in cervical dorsal column axons after peripheral nerve injury is closely correlated with the ability of these axons to respond to local cues capable of eliciting axon growth (Richardson and Verge, 1986).

Although they rarely regenerate spontaneously, injured axons in the mammalian CNS often grow long distances when the CNS environment distal to a lesion is replaced with a more favorable growth pathway, such as a transplanted segment of peripheral nerve (David and Aguayo, 1981; Benfey and Aguayo, 1982; Vidal-Sanz et al., 1987). CNS axons are not always capable of such regeneration, however. In contrast to the PNS, CNS axons injured so as to leave a long axon stump connected to the neuronal soma rarely regenerate, even if given access to a peripheral nerve segment (David and Aguayo, 1981; Benfey and Aguayo, 1982; Richardson et al., 1982, 1984; Friedman and Aguayo, 1985). The dramatically reduced regrowth elicited

Received Jan. 7, 1991; revised July 8, 1991: accepted July 18, 1991.

This work was supported by U.S. Public Health Service NRSA Fellowship 5 F32 NS08183-02 and Spinal Cord Research Foundation Grant 790-01 to D.J.S. and by NIH Grant NS20178 and the Isabelle Niemela Fund.

Correspondence should be addressed to Pate Skene, Department of Neurobiology, Box 3209, Duke University Medical Center, Durham, NC 27710.

a Present address: Department of Physiology, Queens University, Kingston, Canada K7L 3N6.

Copyright (C) 1991 Society for Neuroscience $0270-6474 / 91 / 113738-14 \$ 05.00 / 0$ from such distally axotomized cells, compared to more proximally injured CNS neurons, indicates that a long proximal axon stump remaining within the CNS environment in some way impedes the ability of the neuron to initiate or sustain axon regeneration.

A long CNS proximal stump might impede regeneration by influencing either retrograde signaling pathways that provoke cell body responses preparatory for growth, or the anterograde relay of those responses to the emerging growth cones, or both. One population of neurons offers a unique opportunity to dissociate the retrograde and anterograde steps in the regenerative response to axotomy. These are neurons of the lumbar dorsal root ganglia (DRG) whose central axon branches ascend the full length of the spinal cord dorsal columns to terminate in the dorsal column nuclei. When these CNS branches are interrupted distally, in the cervical spinal cord, and are given access to a grafted segment of peripheral nerve, virtually none of them (less than one cell per animal) regenerates (Richardson et al., 1982; Richardson and Issa, 1984). However, each of these DRG neurons also extends an axon branch peripherally, through the sciatic nerve, and those peripheral axons do regenerate when injured. Sciatic nerve injury also induces a dramatic increase in the ability of the centrally projecting DRG axons to regenerate when they are provided with peripheral nerve grafts placed in the cervical spinal cord (Richardson and Issa, 1984; Richardson and Verge, 1986). This observation indicates that axotomyinduced metabolic changes that underlie the acquisition of regenerative capability can be relayed along long axons embedded in the CNS environment.

The mechanisms conveying regenerative cell body responses to the distal ends of injured axons are unknown. One likely mechanism is the anterograde axonal transport of proteins whose expression is altered in response to axotomy. Some of these proteins, including the major cytoskeletal proteins altered after axotomy (Hoffman, 1989), are delivered into the injured axons by slow axonal transport (groups IV and V of Willard et al., 1974; Lorenz and Willard, 1978). However, the altered pattern of slowly transported proteins appears to be routed only to the injured peripheral axon branch and not the uninjured central branch of DRG neurons (Oblinger and Lasek, 1988). Therefore, slow axonal transport is unlikely to be the mechanism relaying the effects of peripheral axotomy to central axons of DRG neurons. In contrast, at least some of the rapidly transported proteins induced after peripheral axotomy of DRG neurons are routed both to the peripheral axons and through the centrally projecting axons in the dorsal root (Bisby, 1981). It is not known whether these axotomy-induced, rapidly transported proteins 
continue along the central DRG axons after they enter the spinal cord, or whether delivery and deposition of these proteins may be impeded in long axons lying within the CNS environment.

Here, we examine the fate of one axotomy-induced protein, GAP-43, after it reaches the CNS segments of peripherally injured DRG axons. GAP-43 is the most extensively studied member of a set of growth-associated proteins (GAPs; Skene and Willard, 1981a,b; reviewed in Skene, 1989), which are expressed transiently during developmental axon outgrowth in most neurons, reinduced by axotomy in a wide range of neurons that can carry out successful axon regeneration, and subsequently transported into the injured axons in concert with the most rapidly moving group of axonally transported proteins (group I of Willard et al., 1974; Skene and Willard, 1981a,b). Upon reaching axon terminals, GAP-43 accumulatcs to bccomc onc of the most abundant components of axonal growth cones (Skene and Willard, 1981c; Meiri et al., 1986; Skene et al., 1986; Goslin et al., 1990). Thus, GAP-43 is itself one candidate to mediate some aspects of axon regeneration. More generally, we use GAP43 as an indicator of the ability of rapid anterograde transport to deliver axotomy-induced proteins effectively to both the PNS and CNS segments of DRG axons.

After distal axotomy in mature mammalian CNS, GAP-43 and several other GAPs fail to be induced or transported at elevated levels along the proximal axon stumps (Skene and Willard, 1981b; Redshaw and Bisby, 1984; Kalil and Skene, 1986; Reh et al., 1987). Because expression of GAPs remains low in the neuronal cell bodies under these circumstances (Bisby et al., 1990; Doster et al., 1991), it is difficult to determine whether the injured CNS axons would support effective anterograde delivery of GAPs if they were expressed. By monitoring the fatc of GAP-43 in CNS segments of DRG axons after its synthesis has been induced by peripheral nerve injury, we sought to answer two questions: (1) Is the delivery and deposition of GAPs in long axons within the CNS environment as effective as in PNS axons? (2) Does accumulation of GAPs in dorsal column axons correlate with changes in the regenerative propensity of those axons?

\section{Materials and Methods}

Surgery. Adult male Sprague-Dawley rats (180-200 gm) received one of two types of sciatic nerve lesion, under ketamine and chloral hydrate anesthesia. Crush lesions were performed on rats by exposing the sciatic nerve in the mid thigh and crimping it for $10 \mathrm{sec}$ tightly with forceps at a site approximately $1 \mathrm{~cm}$ distal to the sciatic notch and $6-8 \mathrm{~cm}$ from the L4 and L5 DRG. The crush lesion site was marked, either with a single, loosely encircling suture of 6-0 surgical silk, or by dipping the tips of the forceps in powdered charcoal. Resection lesions were performed by excising a $1 \mathrm{~cm}$ segment of the sciatic nerve from 1 to $2 \mathrm{~cm}$ distal to the sciatic notch. In some cases, the proximal nerve stump was ligated. Following nerve resection, the proximal and distal stumps remained free in the leg, where they retracted away from each other. After either type of lesion, the skin was sutured, and the animals were allowed to survive from $1 \mathrm{~d}$ to 10 weeks.

Sciatic nerve tissue was obtained post-mortem for identifying the lesion site and verifying that the sciatic nerve maintained gross anatomic continuity, or discontinuity, following crush or resection lesions, respectively. Affected DRG were identified by tracing the nerve back to the appropriate spinal root level (reliably, L4 and L5). The corresponding dorsal and ventral roots were dissected, as were the DRG themselves, the segment of peripheral nerve extending $3-4 \mathrm{~cm}$ distal to the DRG, and a $1 \mathrm{~cm}$ segment including the lesion site (crush) or proximal stump (resection). Corresponding tissue was taken from the unlesioned, control side of every rat. Tissue samples were frozen on dry ice and stored at $-70^{\circ} \mathrm{C}$.
Antibody production. Balb/c mice were immunized with a preparation of GAP-43 partially purified from neonatal rat brain by preparative isoelectric focusing (Radola, 1984) and suspended in adjuvant (Ribi ImmunoChem Research, Inc.). Spleen cells from immunized mice were fused with myeloma cells, and hybridoma cultures were isolated and cloned in selective medium, according to standard methods (Köhler and Milstein, 1975; Galfrè and Milstein, 1981). Antibody-secreting cultures were identified with a dot blot assay (Bennett and Yeoman, 1983) using partially purified GAP-43. Monospecificity for GAP-43 was confirmed using Western blotting. Antibody-producing cell lines were used to produce ascites fluid in Balb/c mice. Antibody 9-1E12 was used for all of the Western blotting studies. Immunocytochemical studies relied primarily on antibody $9-1 \mathrm{E} 12$, but additional tissue sections were probed with antibodies 6-2G3, 8-1G8, 8-2F9, 9-1D1, and 10-1G5.

Western hlots. Western hlot analysis was performed on 36 crushlesioned, 24 resection-lesioned, and 2 unoperated control rats. Tissue samples were homogenized in $1 \mathrm{ml}$ of $50 \mathrm{~mm}$ Tris- $\mathrm{HCl}, \mathrm{pH} \mathrm{7.5,5} \mathrm{mM}$ EDTA, and $5 \mathrm{~mm}$ dithiothreitol; debris was removed by low speed centrifugation; and membrane pellets were prepared by centrifugation at $100,000 \times g$ for $30 \mathrm{~min}$. The pellets were extracted by sonication in $1 \mathrm{ml}$ of $0.2 \%$ SDS (or $2 \%$ octyl glucoside, for isoelectric focusing) and centrifuged again at $100,000 \times g$. Protein content of the supernatant was estimated by measuring its absorbance at $280 \mathrm{~nm}$. Supernatant was dried under vacuum, and then resolubilized and electrophoresed in a $12 \%$ acrylamide SDS gel (Laemmli, 1970), or resolved for $5500 \mathrm{~V}$-hr on a $5 \%$ acrylamide isoelectric focusing gel with ampholytes adjusted

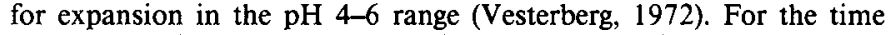
course analysis, each sample contained $150 \mu \mathrm{g}$ protein. Gels were electroblotted to nitrocellulose paper for $1 \mathrm{hr}$ at $1 \mathrm{~mA} / \mathrm{cm}^{2}$ in a semidry apparatus using a buffer consisting of $40 \mathrm{~mm}$ AMPSO [3-(1,1-dimethyl2-hydroxyethyl)amino-2-hydroxy-propanesulfonic acid; $\mathrm{pH} 9.5$ ] in $20 \%$ methanol. After transfer, the residual protein within gels was visualized by silver staining (Morrisey, 1981) to confirm that the same amount of protein had been loaded in each lane, and the nitrocellulose paper was stored frozen in a blocking solution composed of $0.5 \%$ albumin and $2 \%$ horse serum in PBS (10 mM sodium phosphate and $0.9 \%$ sodium chloride, $\mathrm{pH}$ 7.5). After thawing, the presence of GAP-43 on nitrocellulose blots was detected with monoclonal antibody 9-1E12, specific for rat GAP-43, at a dilution of 1:2000 in blocking solution. The antibody binding pattern was developed using avidin/biotin/peroxidase histochemistry (ABC Kit; Vector Laboratories) according to the manufacturer's instructions, except that the biotinylated secondary antibody stock solution was preabsorbed with $2 \mathrm{vol}$ of rat serum for $2 \mathrm{hr}$ before use and all reagents were diluted by an additional factor of 2.5 .

Immunocytochemistry. Six unoperated rats, 19 crush-lesioned rats, and 21 resection-lesioned rats were perfused transcardially under chloral hydrate anesthesia with $4 \%$ paraformaldehyde in $0.1 \mathrm{M}$ phosphate buffer. Spinal cords were dissected and postfixed for $4 \mathrm{hr}$, then rinsed in PBS overnight. Sections $40 \mu \mathrm{m}$ thick were cut using a Vibratome in the transverse, sagittal, or horizontal plane at lumbar, thoracic, and cervical spinal cord levels. Sections were treated for 30-60 min with blocking solution plus $0.1 \%$ Triton $\mathrm{X}-100$, incubated in monoclonal antibody 9-1E12 for 12-24 hr at dilutions of 1:10,000-200,000 in blocking solution, and washed overnight in PBS. Additional sections were incubated in monoclonal antibodies 6-2G3, 8-1G8, 8-2F9, 9-1D1, or 10$1 \mathrm{G} 5$ for $36 \mathrm{hr}$ at dilutions of 1:100-5000, and then washed for $1 \mathrm{hr}$ in PBS. The primary antibody binding patterns were developed using avidin/biotin/peroxidase histochemistry (ABC Kit; Vector Laboratories) according to the manufacturer's instructions, except that the biotinylated secondary antibody stock solution was preabsorbed with 2 vol of rat serum for $2 \mathrm{hr}$ before use. Peroxidase activity was visualized using 3,3'-diaminobenzidine (DAB) as the chromagen. DAB reaction product was enhanced by treatment in $0.005 \%$ osmium tetroxide for $1 \mathrm{hr}$ after defatting the sections in chloroform/ethanol overnight.

$D R G$ neuron counts. Two unoperated and seven crush-lesioned rats were perfused as above. From these, $34 \mathrm{~L} 4$ and L5 DRG were dissected, cryoprotected in $20 \%$ sucrose in PBS overnight, and then frozen in embedding medium. Ten-micrometer sections were cut using a cryostat and collected on gelatin-subbed slides. Sections were processed for 9-1E12 immunocytochemistry as described above. One section from each ganglion was chosen at random and used for quantitative analysis. A $1 \mathrm{~mm}^{2}$ field of view (usually encompassing most neurons present on the section) was framed with a reticule, and each neuron was scored for 9-1E12 immunoreactivity. Neurons with no DAB reaction product visible in their cytoplasm were counted as unlabeled. Neurons with visible 
Figure 1. A, Schematic diagram illustrating axonal branching pattern of DRG neurons. $D C$, dorsal columns; $D H$, dorsal horn; $V H$, ventral horn. 1 , ventral root; 2 , dorsal root; 3 , DRG; 4, proximal sciatic nerve; 5 , distal sciatic nerve including lesion site (open $\times$ ). The principal paths of small-caliber DRG axons (dashed lines), large-caliber DRG axons (solid lines), and motor axons (dotted line) are indicated. B, Transverse tissue section taken through the lumbar spinal cord of an unoperated adult rat and immunostained with antibody 9-1E12 (1:20,000). $G F$, gracile fasciculus; $L T$, Lissauer's tract; $C S T$, corticospinal tract. Scale bar, $500 \mu \mathrm{m}$. $C$, Transverse tissue section through the lumbar spinal cord of an unoperated adult rat immunostained with preimmune mouse serum $(1: 1000)$.

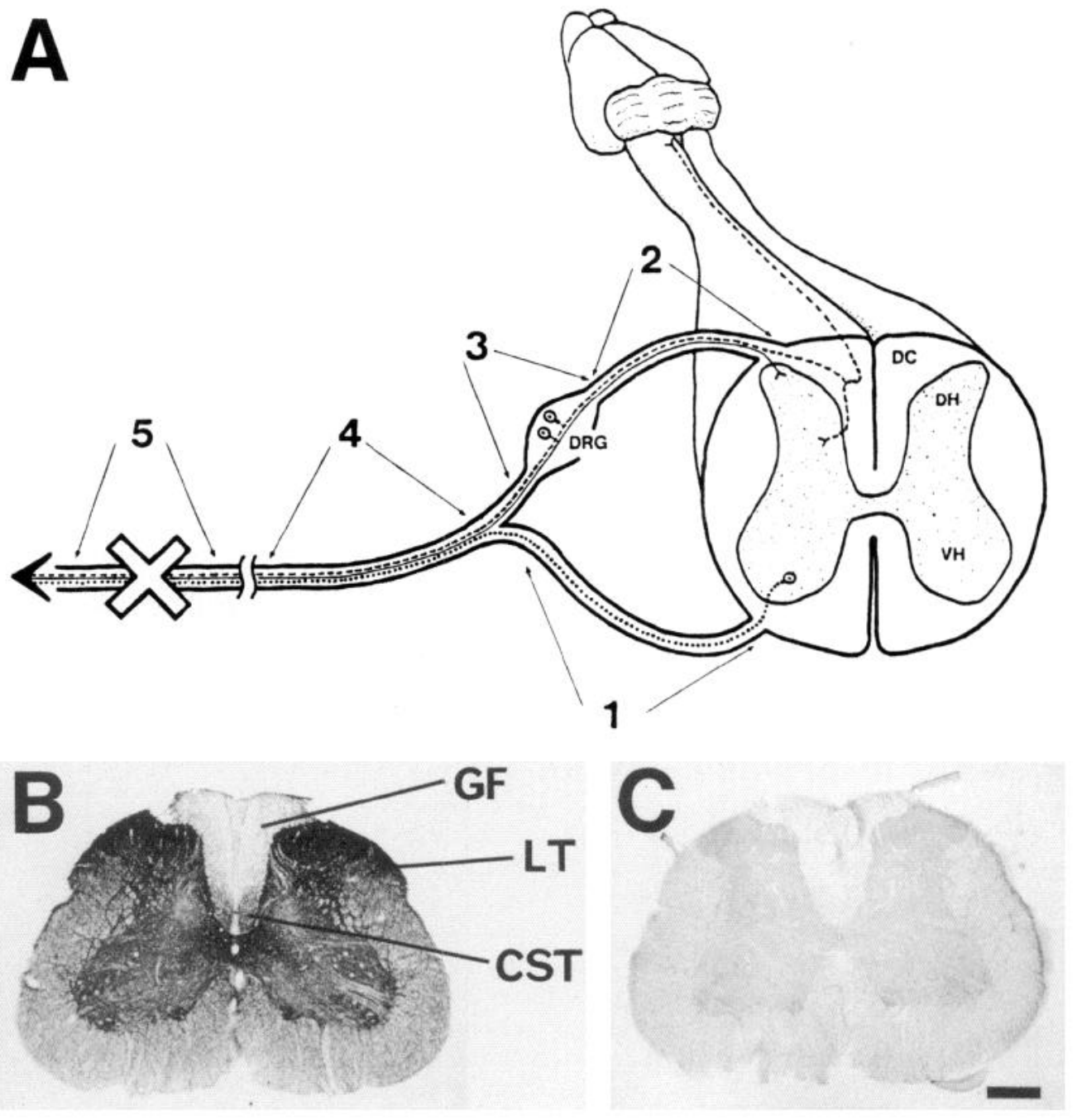

DAB reaction product were counted as labeled; this category was further subdivided into lightly labeled and heavily labeled categories.

\section{Results}

Figure $1 A$ illustrates the organization of axons from the rat lumbar (L4 and L5) DRG neurons examined in these experiments. A peripheral axon branch from each sensory neuron enters the sciatic nerve and, along with motor axons, travels long distances to innervate the tissues of the hindlimb. A central axon branch from each sensory neuron transits the dorsal root to enter the spinal cord; within the dorsal root, these centrally projecting axons remain within a glial environment typical of the PNS. Centrally projecting DRG axons entering the spinal cord can be divided into two subpopulations. Fine-caliber dorsal root axons synapse upon CNS neurons of the spinal cord in or near the segment at which they enter the cord. Large-caliber dorsal root axons can extend collateral branches that also synapse locally, but also can ascend long distances in the gracile fasciculus of the dorsal columns to reach the caudal medula, where they synapse upon neurons of the nucleus gracilus. These long, ascending dorsal column axons are the primary focus of this study.

\section{GAP-43 distribution prior to injury}

We have used monoclonal antibodies to assess the steady-state accumulation of GAP-43 in DRG neuron cell bodies and axon segments before and after peripheral axotomy. Most of the experiments described here employed antibody 9-1E12, which appears to recognize an epitope available on all known forms of mammalian GAP-43 (Fig. 2). The specificity of this antibody for GAP-43 is illustrated by its recognition of a single protein band on Western blots of brain, spinal cord, or sciatic nerve proteins separated by standard SDS-PAGE (Fig. $2 A, B, D$ ). Isoelectric focusing, however, resolves GAP-43 into four major isoforms varying in charge (Zwiers et al., 1985; Skene and Verág, 1989). Antibody 9-1E12 is able to recognize all of these charged isoforms of the protein (Fig. 2B). Previous work has indicated further that antibody 9-1E12 SDS-PAGE gels can recognize unmodified GAP-43 produced by in vitro translation of GAP43 mRNA (Skene and Virág, 1989) and can recognize both fatty acylated and deacylated forms of the protein (Skene and Virág, 1989; Patterson and Skene, 1991). 9-1E12 immunoreactivity therefore provides a reliable and specific indicator of total GAP43 abundance that is relatively insensitive to posttranslational modifications of the protein. 

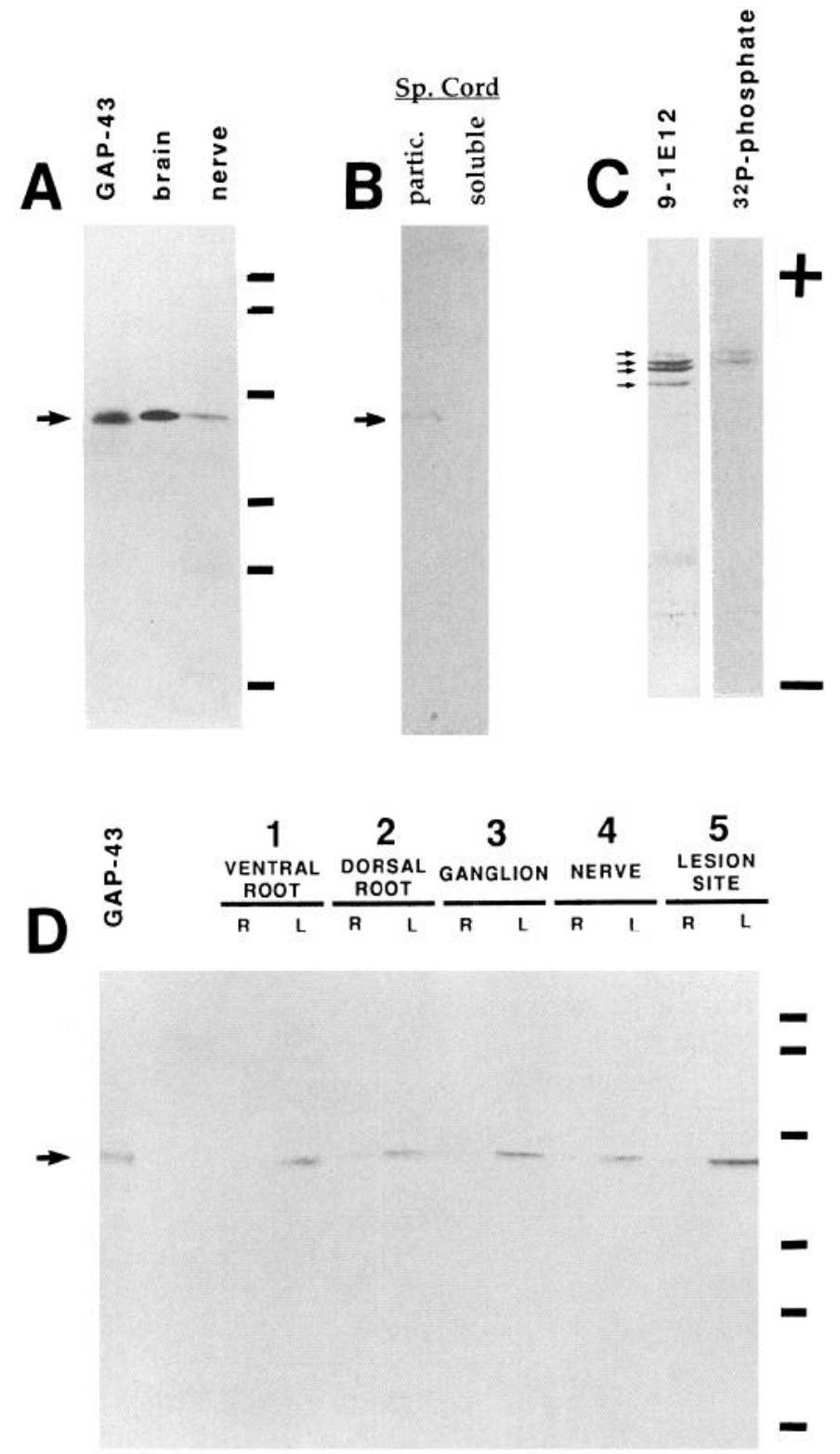

Figure 2. Specificity of antibody $9-1 \mathrm{E} 12$ for GAP-43 and relative insensitivity to posttranslational modifications. $A$, Western blot of proteins resolved by standard SDS-PAGE. Lane 1, partially purified GAP43; lane 2, neonatal brain membrane proteins; lane 3, regenerating sciatic nerve membrane protein. Arrow indicates position of GAP-43. Markers at right indicate molecular weight standards of $130,75,50$, 39,27 , and $17 \mathrm{kD}$. B. Specificity of 9-1E12 for GAP-43 in spinal cord. Lumbar through cervical spinal cord was removed from a rat $7 \mathrm{~d}$ after sciatic nerve crush, homogenized, and separated into particulate (lane I) and soluble (lane 2) fractions by centrifugation at 100,000 $\times \mathrm{g}$. Approximately $100 \mu \mathrm{g}$ of each fraction was separated by SDS-PAGE, blotted, and probed with antibody 9-1E12. The arrow indicates the position of a GAP-43 standard, which comigrates with the single immunoreactive protein band enriched in the particulate fraction. $C$, Recognition of multiple charged isoforms of GAP-43. Growth cone membrane proteins (Pfenninger et al., 1983) were resolved by one-dimensional isoelectric focusing in a narrow $\mathrm{pH}$ range (4-6). The acidic end of the gel is at the top. Lane 1, Western blot of growth cone proteins, probed with antibody 9-1E12; four isoelectric isoforms are recognized (arrows). Lane 2, Autoradiograph of growth cone proteins labeled by metabolic incorporation of ${ }^{32} \mathrm{P}$-phosphate; the two most acidic isoforms only are labeled. Note that 9-1E12 recognizes both phosphorylated and unlabeled bands. $D$, Specificity of antibody $9-1$ E12 for GAP-43 in samples of nerve roots, ganglia, and sciatic nerve after peripheral nerve injury.
In the spinal cords of unoperated rats, substantial GAP-43 immunoreactivity was present in all regions of the gray matter, as neuropilar labeling (Fig. $1 B$ ). Especially dense labeling was seen in the dorsal horn, particularly the substantia gelatinosa, where many fine-caliber DRG axons terminate. A generally lower density of GAP-43 immunoreactivity was found in the white matter tracts of the spinal cord. The ventral and lateral white matter columns displayed only modest axonal labeling, except for dense labeling of Lissauer's tract, which contains fine-caliber DRG axons destined to synapse in the substantia gelatinosa. In the dorsal columns, the gracile and cuneate fasciculi, which contain ascending, large-caliber DRG axons, were among the least densely labeled areas of the spinal cord. Ventrally adjacent in the dorsal columns, the corticospinal tract displayed moderate immunoreactivity. This pattern of GAP-43 immunoreactivity was identical to the pattern observed in the contralateral spinal cord after sciatic nerve lesions. In the medulla, moderately heavy labeling was observed in the target nuclei of ascending DRG axons, the nucleus gracilis and the nucleus cuneatus (not shown). Control sections processed in parallel, but probed with nonimmune mouse serum, showed no labeling (Fig. 1C).

\section{Accumulation in extraspinal nerve segments after injury}

Before it could be transported into the central axons of the dorsal column, GAP-43 must be induced in DRG cell bodies and transported not only into the injured peripheral axon branches, but also into the centrally projecting branches in the dorsal root. Previous studies have shown that a minority of DRG neurons express high levels of GAP-43 mRNA in normal, unoperated adult rats (Hoffman, 1989; Verge et al., 1990) but that sciatic nerve lesions induce GAP-43 mRNA and protein synthesis (Basi et al., 1987; Hoffman, 1989; Tetzlaff et al., 1989; Van der Zee et al., 1989; Verge et al., 1990) in the majority of neurons in the L4 and L5 DRG. In the present study we found that the steady-state accumulation of GAP-43 in the cell bodies and all portions of DRG axons lying in a PNS environment, assessed by $9-1 \mathrm{E} 12$ immunoreactivity, closely follows the pattern of mRNA expression.

In unoperated rats, a mean of $46 \%$ of neurons in the L4 and L5 DRG displayed some degree of immunocytochemical labeling using antibody 9-1E12. Most of these neurons were lightly labeled, but $7.2 \%$ of uninjured DRG neurons were heavily labeled (Fig. 3). By 1 week after a sciatic nerve crush distal the sciatic notch, a mean of $84 \%$ of neurons in the ipsilateral L4 and L5 DRG could be labeled, with $43.4 \%$ of neuronal somata heavily stained (Fig. 3). There was no further increase in total GAP-43-immunoreactive neurons, or in the numbers of heavily immunoreactive cells, beyond the first week after nerve injury. At 2 weeks, for example, $77 \%$ of cell bodies in the ipsilateral DRG could be stained with $9-1$ E12, with $45.4 \%$ of DRG neurons heavily labeled. In the ganglia contralateral to the lesions, the numbers of labeled DRG neurons were not significantly

Crude membrane samples were prepared from the right ( $R$; unoperated) and left $(L)$ lumbar ventral and dorsal roots, DRG, and sciatic nerve of an adult rat $8 \mathrm{~d}$ following left sciatic nerve crush. Proteins were separated by SDS-PAGE, blotted, and probed with antibody 9-1E12. Numbers correspond to tissue samples indicated in Figure $1 A$. Markers at right indicate molecular weight standards as in $A$. The first lane (GAP43) contains $100 \mathrm{ng}$ of partially purified GAP-43 from growth cone membranes (arrow). 

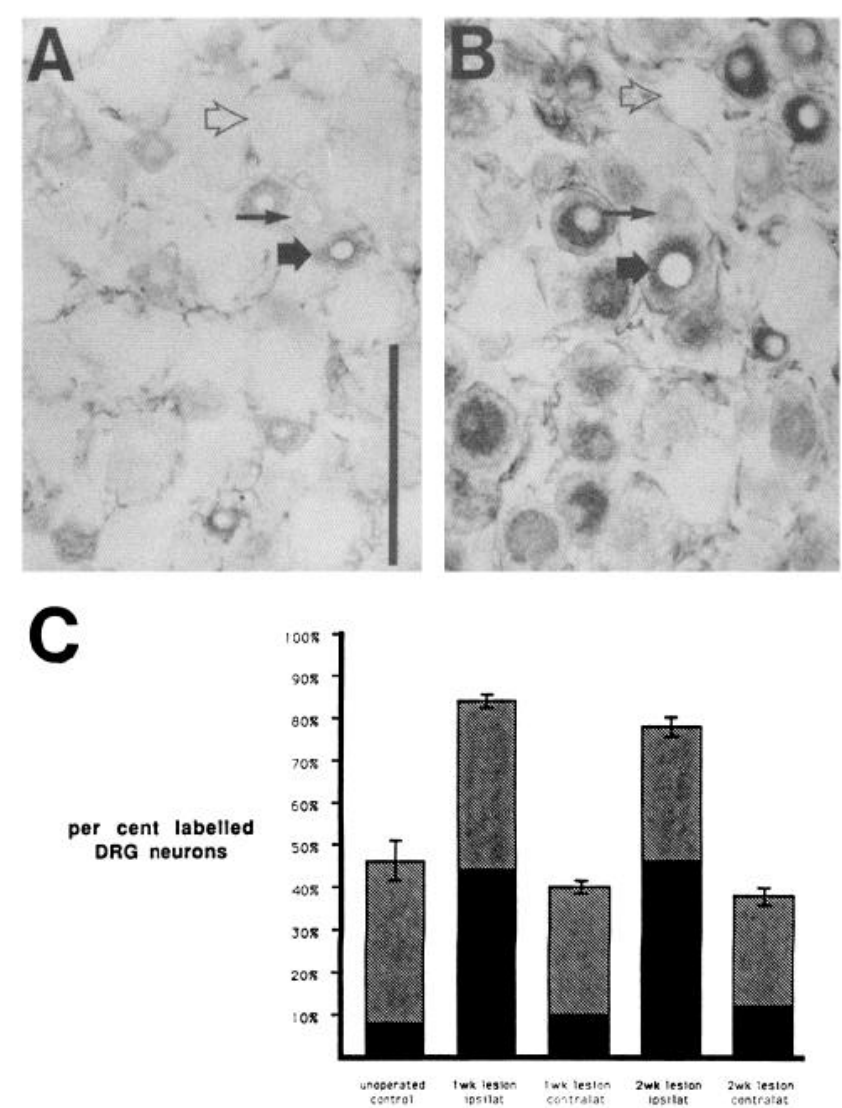

Figure 3. Accumulation of GAP-43 in DRG neuron cell bodies before and after sciatic nerve injury. $A$ and $B$, Tissue sections through a right $(A)$ and a left $(B)$ DRG taken from a rat 2 weeks following a left sciatic nerve crush and immunostained with antibody 9-1E12 (1:20,000). Examples of unlabeled (open arrows), lightly labeled (thin arrows), and heavily labeled (thick arrows) cell bodies are indicated. Scale bar, 100 $\mu \mathrm{m}$. $C$, Bar graph showing percentages of labeled neurons seen in DRG from unoperated control rats and in ipsilateral and contralateral DRG taken 1 or 2 weeks following sciatic nerve crush. Solid bars represent heavily labeled cell bodies, and cross-hatched bars represent lightly labeled cell bodies. Error bars indicate SEM for all labeled cells. The difference in percentage of cells labeled is significantly different between control DRG and DRG ipsilateral to sciatic nerve injury at both 1 and 2 weeks ( $p<0.001$, Student's $t$ test). The percentage of cells labeled in the contralateral ganglia is not significantly different from unoperated controls at either survival time $(0.1<P<0.5)$.

different from controls (Fig. $3 \mathrm{C}$ ). It has been reported that sciatic nerve lesions at a similar location axotomize $70 \%$ of the $\mathrm{L} 4$ and L5 DRG neurons and that $30 \%$ of the axotomized neurons die (Himes and Tessler, 1989). Our counts of GAP-43-immunoreactive cells are therefore consistent with the interpretation that $45 \%$ of uninjured neurons, and $100 \%$ of axotomized neurons, express GAP-43 and have accumulated detectable amounts of the protein in their cell bodies by 1 week after injury.

We used Western blotting to examine the distribution of GAP43 accumulating along the extraspinal, PNS portions of DRG neurons subsequent to its initial induction after sciatic nerve lesions. Figure $4 A$ shows that the steady-state levels of GAP-43 in DRG, in peripheral nerve, and in dorsal roots increase above the levels in contralateral control nerves $2-4 \mathrm{~d}$ after either crush or resection lesions. During the first week after either type of lesion, GAP-43 immunoreactivity accumulates more or less uniformly in each of these tissue segments, with the exception of a preferential accumulation of the protein near the lesion site, containing the growth cones forming at the distal ends of the injured axons. Both the timing and the relative intensity of GAP43 accumulation are similar between the dorsal roots, containing the uninjured, centrally projecting axons of the DRG neurons, and tissues containing cell bodies and proximal segments of injured peripheral axons.

Beginning about 4 weeks after crush lesions, the amount of GAP-43 immunoreactivity on Western blots began to decline in lesion-side tissue samples, subsiding to near control levels by 6-10 weeks (Fig. 4B). In marked contrast, following resection lesions, the GAP-43 immunoreactivity in dorsal root, DRG, and proximal peripheral nerve and lesion site samples remained elevated for as long as 10 weeks, the longest time point examined.

\section{Slow proximodistal accumulation along the dorsal columns}

To follow the fate of newly induced GAP-43 in medial division DRG axons after they enter the CNS environment of the ascending dorsal columns, we used immunocytochemistry of spinal cord sections prepared from rats 1,2 , and 3 weeks after sciatic nerve crush or resection lesions. These lesions are similar to those shown to enhance the regenerative ability of DRG axons in the dorsal columns (Richardson and Issa, 1984; Richardson and Verge, 1986). Regardless of the type of peripheral lesion, the initial accumulation of GAP-43 in these ascending axons followed the same pattern; accumulation of 9-1E12 immunoreactivity was first apparent only in more proximal segments of these axons and subsequently progressed distally.

At the L4 and L5 spinal levels 1 week following a crush or resection lesion, axons displaying robust labeling by antibody 9-1E12 occupied the entire width of the dorsal columns on the operated side (Fig. $5 B$ ). Across the midline of the dorsal columns, on the unoperated side, only much sparser labeling of axons was seen, as in the dorsal columns of unoperated animals. At rostrally adjacent lumbar and low thoracic levels, labeled axons were flanked laterally by unlabeled axons, presumably derived from the DRG above L4 (Fig. $5 A$ ). Spinal cord sections from higher thoracic and cervical levels of 1 week postlesion animals did not display lesion-induced increases in GAP-43 immunoreactivity (Fig. 6).

GAP-43 immunoreactivity was not detectable at cervical levels until 2 weeks after peripheral injury, when axons displaying moderately increased immunoreactivity could be detected ipsilaterally at these more rostral levels (Fig. 6). By 3 weeks after crush or resection lesions of the sciatic nerve, a continuous streak of robustly immunoreactive axons could be traced through the gracile fasciculus from their lumbar zone of entry to the highest cervical levels. At thoracic and cervical spinal levels, the densely labeled axons occupied most of the gracile fasciculus, near the midline. Although reduced in number in rostral spinal cord, the diameter and spatial density of labeled axons in this bundle was similar to that seen at lumbar levels.

In all cases, higher-magnification views showed that GAP-43 immunoreactivity was concentrated in axon shafts $1-4 \mu \mathrm{m}$ in diameter (Fig. 7).

\section{Differential persistence at late postlesion times}

While the initial accumulation of GAP-43 along dorsal column axons followed a similar pattern after either crush or resection of the sciatic nerve, the persistence of GAP-43 in these axons differed dramatically between the two types of lesions. Eight 
A

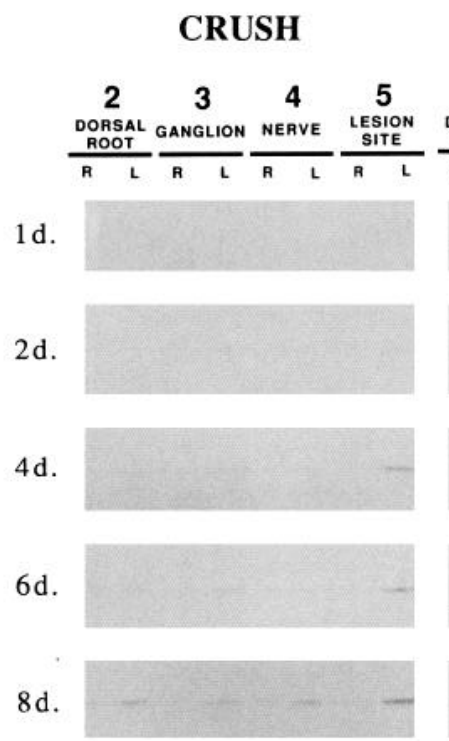

RESECTION
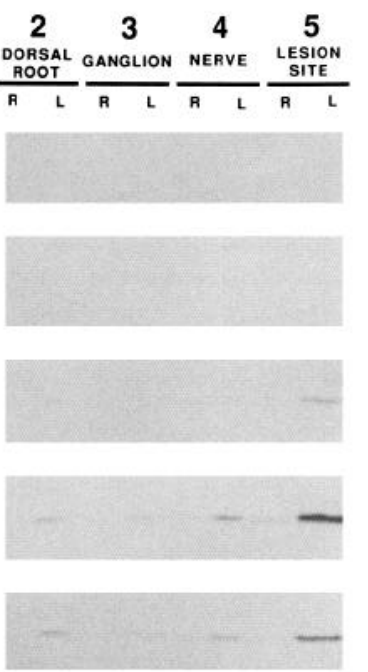

B

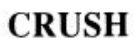

RESECTION

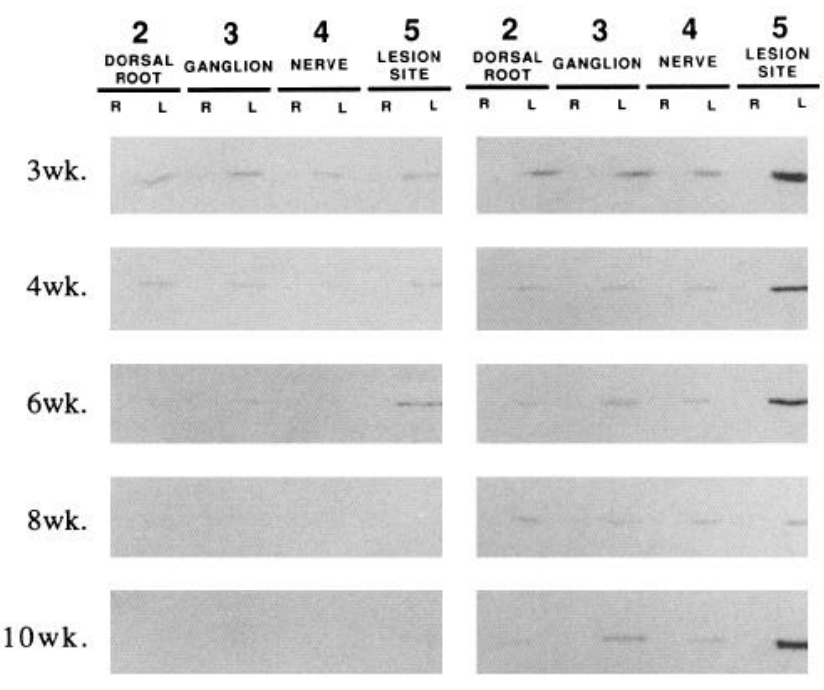

Figure 4. Time course of GAP-43 accumulation in PNS tissues after sciatic nerve injury. Antibody 9-1E12 was used to probe Western blots of sciatic nerve membrane proteins obtained from rats at short $(A)$ or long $(B)$ survival times following sciatic nerve crush or resection lesions. Numbers correspond to tissue samples indicated in Figure $1 A$. $\mathrm{R}$ indicates right (unoperated) side; $L$ indicates left (lesioned) side. GAP-43 begins to increase on the lesioned side by $2 \mathrm{~d}$ and persists for at least 3 weeks after either type of lesion. Accumulation of GAP-43 declines beginning 4-6 weeks after a crush lesion, but persists for at least 10 weeks after resection lesions.

weeks after sciatic nerve resection lesions, the pattern of GAP43 immunoreactivity observed in the dorsal columns was similar to the pattern seen at 3 weeks. Robustly immunoreactive axons ascended from the L4 and L5 levels all the way through the highest cervical levels (Fig. 6) and into the nucleus gracilis in the caudal medulla ipsilateral to the lesion. However, 8 weeks following crush lesions of the sciatic nerve, no increased GAP43 immunoreactivity was seen in the dorsal columns ipsilateral to the lesion. Rather, the appearance of the spinal cords resembled that of control, unoperated animals (Fig. 6).

\section{Immunoreactivity in terminal zones}

At no time after peripheral injury did the nucleus gracilis, a termination zone for ascending lumbar DRG axons, exhibit an increase in overall 9-1E12 immunoreactivity above the substantial labeling observed in unoperated animals. However, in cases in which sciatic nerve injury resulted in cervical dorsal column labeling, it was also possible to trace individual labeled shafts of dorsal column axons derived from lumbar DRG as they entered this nucleus. Similarly, the termination zone of fine-caliber dorsal root axons, in the substantia gelatinosa, was heavily immunoreactive with 9-1E12 both before and after peripheral axotomy.

\section{Studies using other antibodies}

Our results using monoclonal antibody 9-1E12 differ in some important regards from results obtained with other antibodies against GAP-43. The most notable difference is the reported absence of GAP-43 immunoreactivity in the dorsal horn and the dorsal column nuclei in unoperated animals (Woolf et al., 1990). In an effort to clarify the basis for these discrepancies, we examined sections of normal and operated spinal cord with a panel of monoclonal antibodies generated against GAP-43,
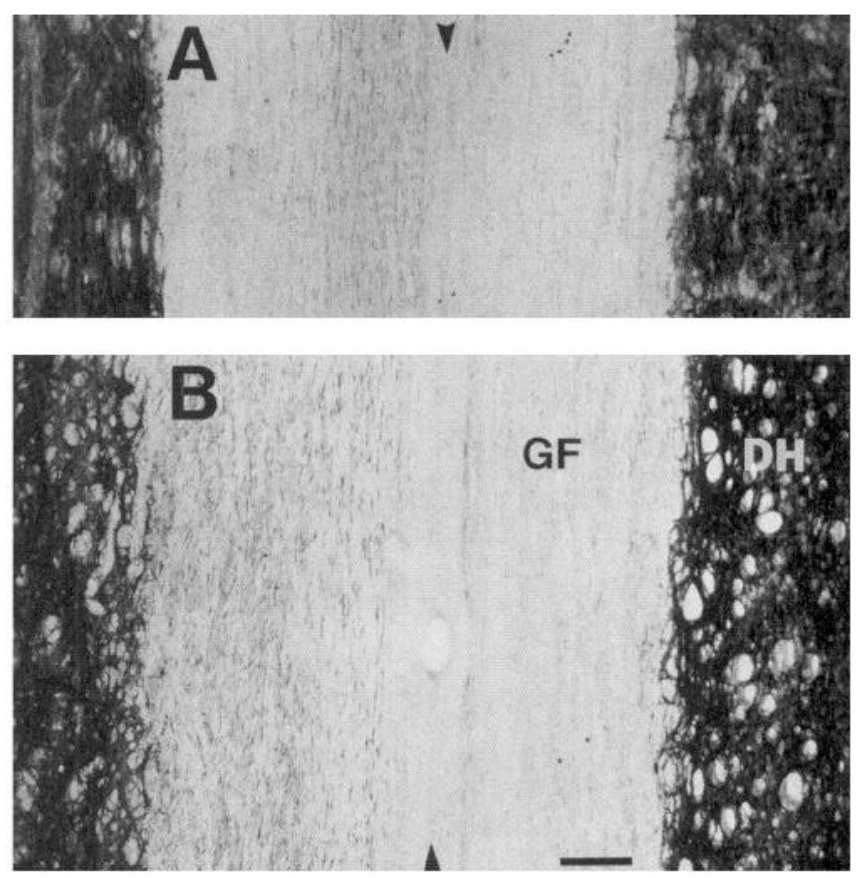

Figure 5. Accumulation of GAP-43 in ascending spinal axons of DRG neurons after peripheral nerve injury. Horizontal tissue sections through the dorsal columns of the thoracic $(A)$ or lumbar $(B)$ spinal cord of a rat 1 week following left sciatic nerve resection, immunostained with antibody 9-1E12 (1:20,000). Ipsilateral to the lesion, increased accumulation of GAP-43 immunoreactivity is visible throughout the width of the gracile fasciculus $(G F)$ at the lumbar level, and in the medial portion of the gracile fasciculus at the thoracic level, corresponding to the distribution of axons ascending from the lumbar DRG. Note also the heavy staining of dorsal horns $(D H)$ on both the injured and contralateral sides. Arrowheads indicate midline. Scale bar, $100 \mu \mathrm{m}$. 


\section{crush}
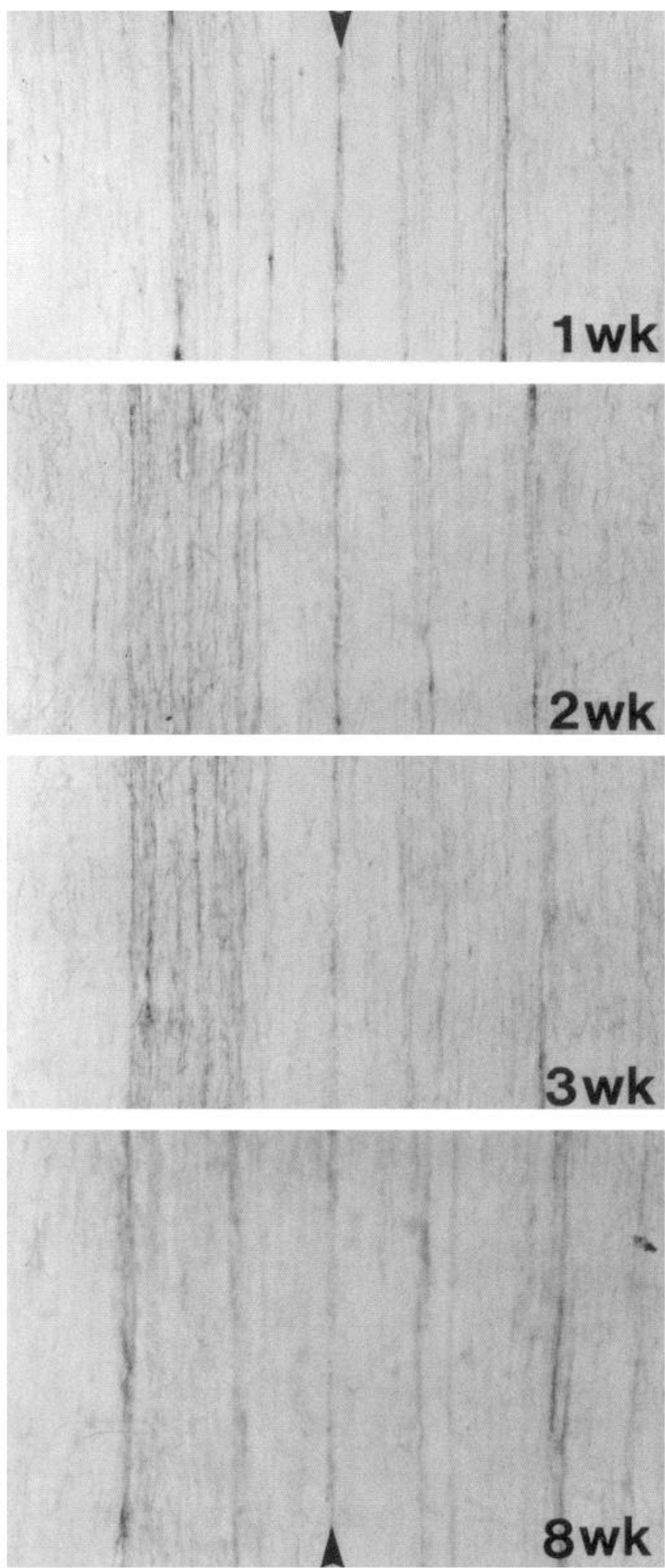

\section{resection}
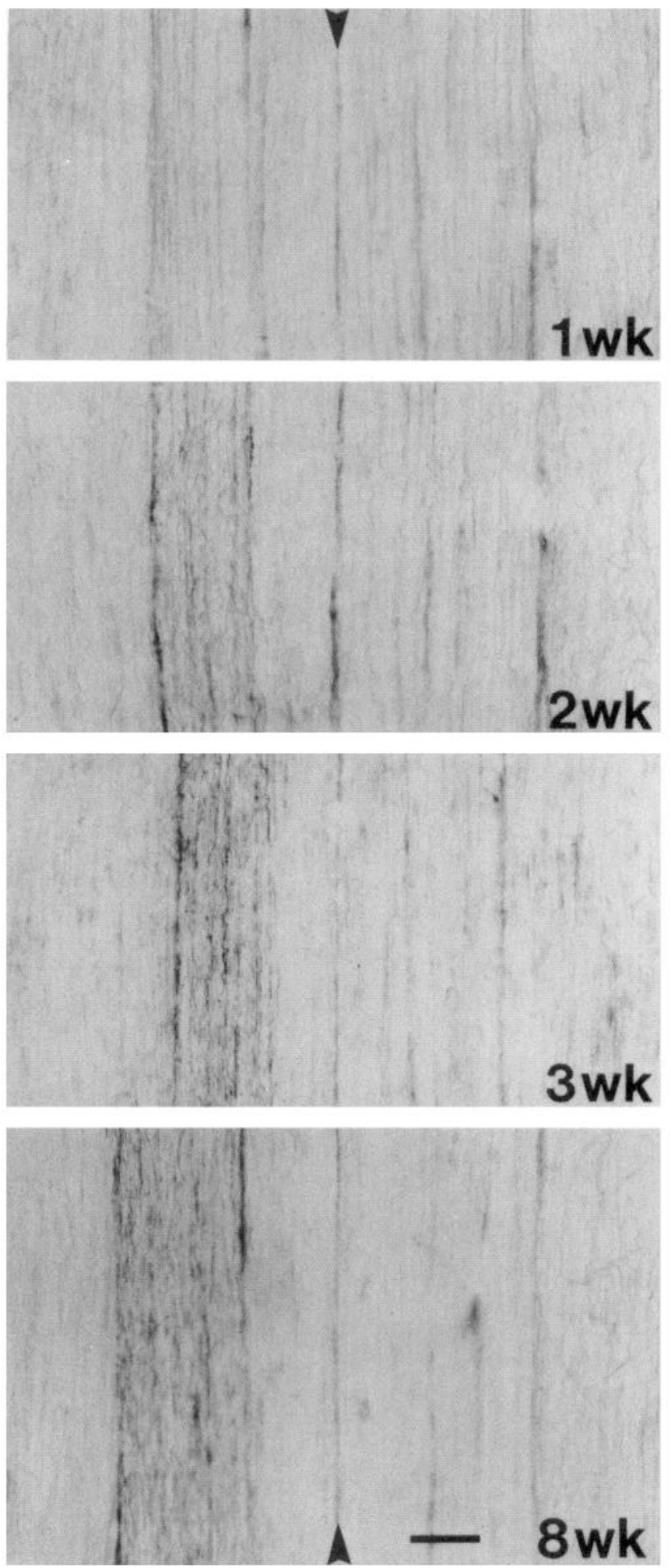

Figure 6. Time course of GAP-43 accumulation in dorsal column axons at the cervical level after sciatic nerve injuries. The panels illustrated horizontal tissue sections through the dorsal columns of the cervical spinal cord at the indicated times following left sciatic nerve crush or resection. Sections were immunostained with antibody 9-1E12 (1:20,000). Arrowheads indicate midline. At this level, a moderate increase in accumulation of GAP-43 immunoreactivity is visible in a discrete strip of axons slightly lateral to the midline, corresponding to the position of axons ascending from the lumbar DRG on the lesioned (left) side, beginning 2 weeks after either type of injury. By 8 weeks after crush injury, GAP-43 immunoreactivity in this portion of the dorsal columns has returned to control levels, while the corresponding axons ipsilateral to the resection lesions retain robust immunoreactivity. Scale bar, $100 \mu \mathrm{m}$. 


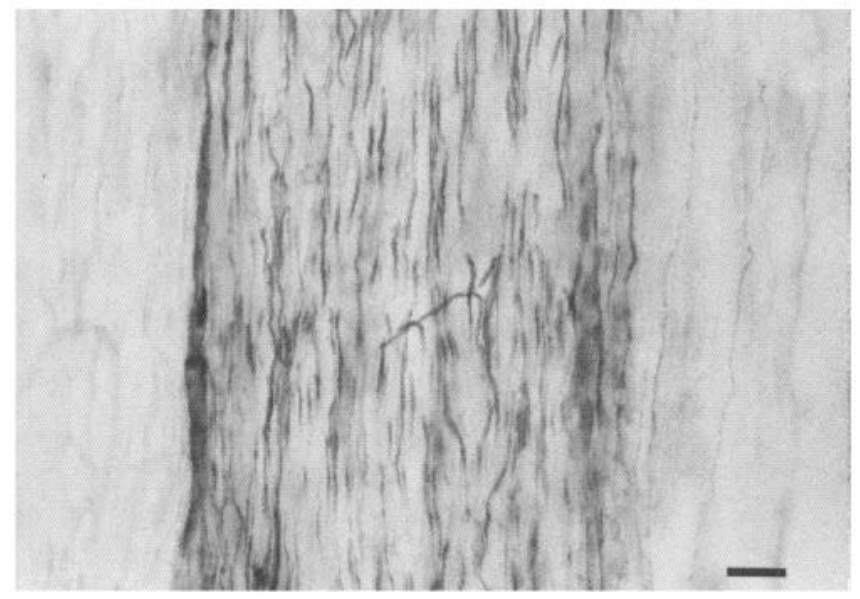

Figure 7. High-magnification view of labeled axons in the cervical dorsal columns 8 weeks following left sciatic nerve resection. The figure shows a horizontal section immunostained with antibody 9-1E12 (1: $20,000)$. The midline is to the right. Scale bar, $20 \mu \mathrm{m}$. comprising antibodies $6-2 \mathrm{G} 3,8-1 \mathrm{G} 8,8-2 \mathrm{~F} 9$, and $9-1 \mathrm{D} 1$, in addition to 9-1E12.

Each of the four additional antibodies yielded asymmetric dorsal horn labeling in animals that had received sciatic nerve crush or resection lesions 2 weeks earlier (Fig. 8). That is, the dorsal horn ipsilateral to the peripheral nerve lesion was consistently labeled more heavily than the contralateral side, but only at spinal levels corresponding to sciatic nerve supply. Antibodies 6-2G3, 8-1G8, 8-2F9, and 9-1D1 displayed much lighter labeling of the substantia gelatinosa corresponding to uninjured sciatic nerves and no labeling of dorsal column axons ipsilateral to nerve injury (Fig. 8). No antibody except 9-1E12 displayed increased labeling of ipsilateral DRG cell bodies or of motor neuron cell bodies following peripheral nerve injury (not shown). Also in contrast to the other antibodies, antibody 9-1E12 consistently labeled the dorsal horn on the uninjured contralateral side and in control animals, and showed no consistent difference between the ipsilateral and contralateral dorsal horns after peripheral nerve injury. These observations show that a large amount of GAP-43 immunoreactivity in the dorsal horn of unoperated animals, and on the side contralateral to a
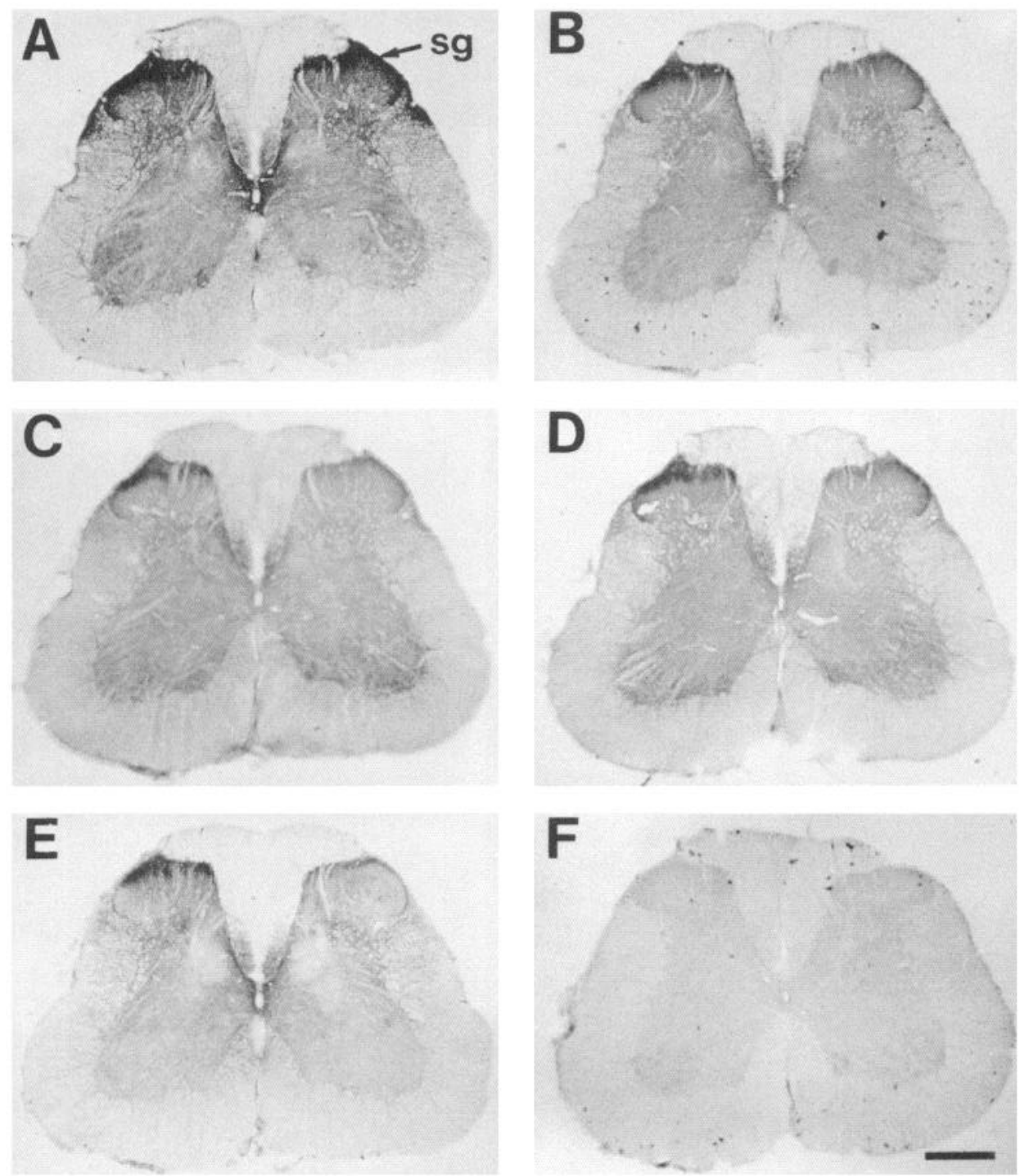

Figure 8. Differential recognition of dorsal horn GAP-43 by additional monoclonal antibodies. Transverse tissue sections were taken through the lumbar spinal cord of a rat 2 weeks following left sciatic nerve crush and immunostained with antibodies 9-1E12 $(A), 6-2 \mathrm{G} 3(B), 8-1 \mathrm{G} 8(C), 8-2 \mathrm{~F} 9(D)$, 9-1D1 $(E)$, or preimmune mouse serum $(F)$. Antibody 9-1E12 was used at a dilution of 1:20,000, and all of the other antibodies were diluted 1:5000. Note that antibody 9-1E12 labels the substantia gelatinosa $(\mathrm{sg})$ heavily on both the lesioned (left) and unlesioned (right) sides, but that the remaining antibodies label the substantia gelatinosa more heavily on the lesioned (left) side. Scale bar, $500 \mu \mathrm{m}$. 


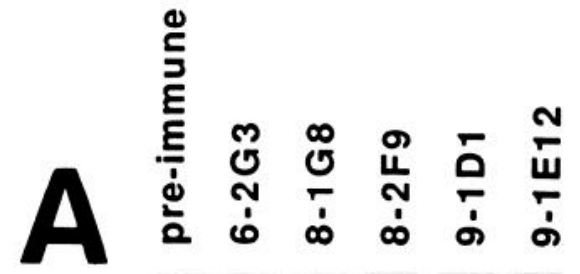

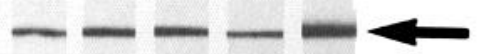

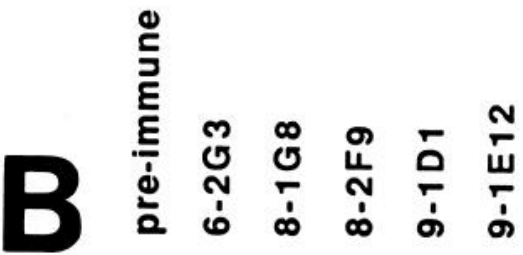

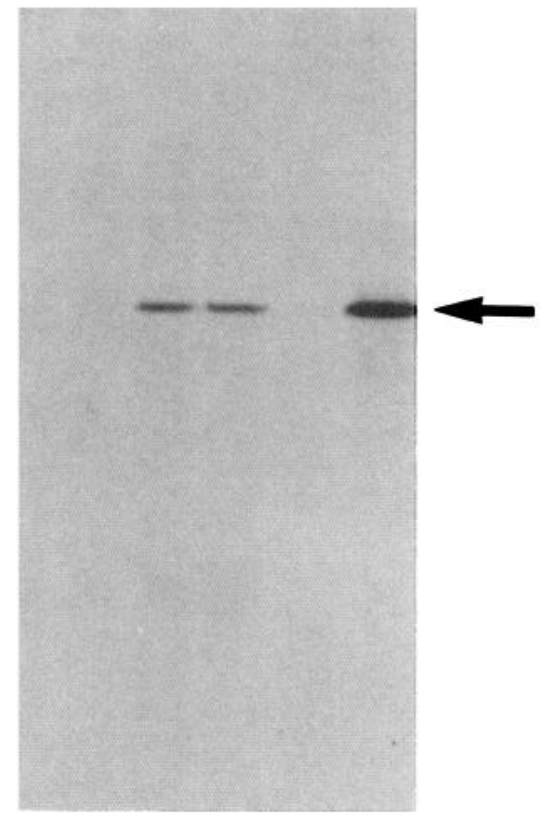

응

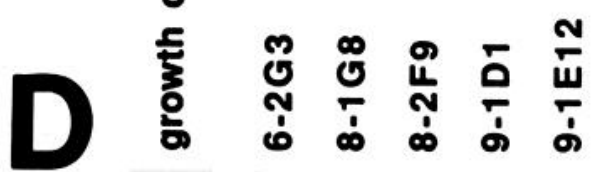

둘

$\pm$

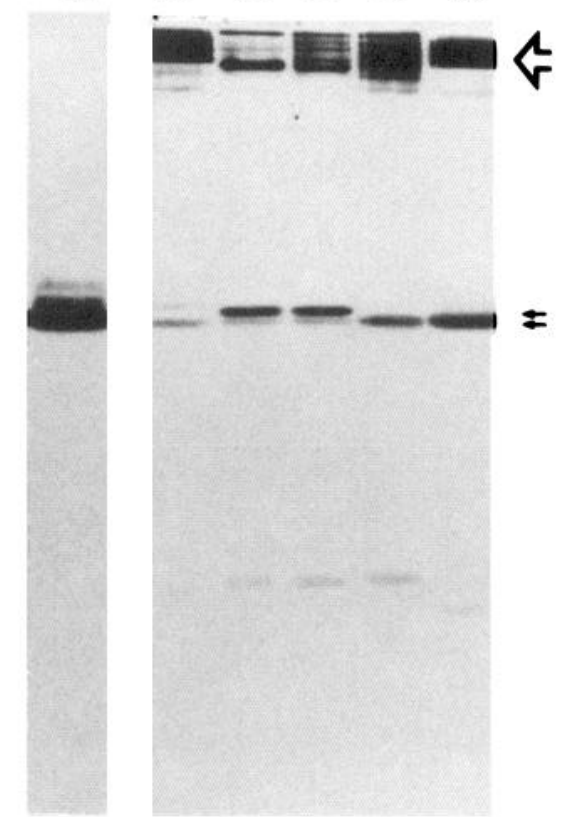


peripheral injury, is detected by only one out of five of our antiGAP-43 antibodies, but that all antibodies detect the GAP-43 in the substantia gelatinosa of the dorsal horn after injury of the corresponding peripheral nerve. Light microscopic analysis does not allow us to determine what portion of the immunoreactivity observed in the dorsal horn resides in DRG axon terminals.

To understand the basis for these differences, we further characterized the specificities of each of the five monoclonal antibodies. Each of the antibodies is highly specific for a single protein band corresponding to GAP-43 on Western blots of proteins separated by standard SDS-PAGE (Fig. 9). However, further characterization of the binding of these antibodies to various isoforms of GAP-43 shows that all of the antibodies except 9-1E12 rccognizc cpitopes sensitive to posttranslational modification (Fig. 9).

\section{Discussion}

We have used a sensitive monoclonal antibody (9-1E12) that recognizes all known forms of GAP-43 to follow the time course of GAP-43 accumulation throughout the extraspinal and spinal segments of DRG neurons after peripheral nerve injuries. The results indicate the following sequence of events: (1) GAP-43 accumulates in a minority of DRG cell bodies in unoperated adult rats but, after peripheral nerve crush or resection, is induced in the remaining neurons and accumulates rapidly in the neuronal somata, the peripheral axon branches, and those portions of the central axon branches lying within the PNS environment of the dorsal root. (2) In large-caliber DRG axons within the spinal dorsal columns, GAP-43 accumulates first in the more proximal axon segments at the lumbar lcvel, but docs not appear in more distal (rostral) segments of these CNS axons until 2-3 weeks after peripheral injury. This initial proximodistal accumulation occurs with a similar time course after either crush or resection lesions of the sciatic nerve. (3) By 8 weeks after a peripheral crush injury, GAP-43 abundance in all seg- ments of the DRG neurons, including long CNS axons of the dorsal column, has declined to near control levels, but the protein persists in all segments of DRG neurons that have undergone a peripheral nerve resection. (4) Structures containing the small-caliber DRG axons (Lissauer's tract and dorsal horn) in unoperated adult rats exhibit considerable immunoreactivity with antibody 9-1E12, which recognizes all known forms of GAP-43, and the abundance of this immunoreactivity is not consistently altered after sciatic nerve lesions. A series of other monoclonal antibodies, all of which display binding that is sensitive to posttranslational modifications of GAP-43, only weakly detect the GAP-43 in these structures in normal animals, but reveal increased immunoreactivity in the dorsal horn atter peripheral nerve injury.

\section{Correlation with regenerative potential}

It has been demonstrated that sciatic nerve resection lesions dramatically enhance the ability of distally injured central branches of the DRG axons to regenerate into a peripheral nerve graft placed in the dorsal columns of the cervical spinal cord (Richardson and Issa, 1984; Richardson and Verge, 1986). In those experiments, peripheral nerve resection resulted in a 100 fold increase in the number of DRG axons that had successfully grown through the peripheral nerve graft after survival times of 2-3 months. However, regeneration of many fewer central DRG axons was detected in peripheral nerve grafts a few months after crush lesions of the sciatic nerve (Richardson and Verge, 1986). The persistence of accumulated GAP-43 in the cervical dorsal columns mirrors these observations. By 2 months after peripheral nerve resection, GAP-43 has been delivered and remains present at the sitc from which regencration was clicitcd in the experiments of Richardson and Verge. Furthermore, the striking difference between crush and resection lesions in promoting GAP-43 accumulation 8 weeks after injury is precisely correlated with the regeneration of dorsal column axons assayed at similar postlesion intervals. It should be emphasized that in our

\footnotetext{
Figure 9. Characterization of additional monoclonal antibodies that recognize GAP-43. $A$, Recognition of GAP-43 on Western blots. Proteins from a growth cone membrane preparation were resolved by standard SDS-PAGE, blotted to nitrocellulose, and probed with preimmune mouse serum or with antibody 6-2G3, 8-1G8, 8-2F9, 9-1D1, or 9-1E12, as indicated. Antibodies were used at dilutions of 1:2000 (9-1E12) or 1:200 (all others). Arrow indicates the position of GAP-43. B, Recognition of the unmodified primary translation product of GAP-43 mRNA. GAP-43 mRNA was transcribed from a cloned cDNA and translated in a commercially supplied wheat germ lysate kit (Boehringer-Mannheim) as previously described (Skene and Virág, 1989). Each antibody was preincubated with $25 \mathrm{mg}$ (wet weight) of agarose beads containing covalently linked goat anti-mouse IgG (HyClone), and the beads were recovered by centrifugation and washed twice with precipitation buffer (1\% Nonidet P-40; 5 mM EDTA in PBS). Antibody-containing beads were then incubated with aliquots of ${ }^{35} \mathrm{~S}$-methionine-labeled translation product, recovered by centrifugation, and washed twice with precipitation buffer. Precipitated translation products were solubilized in SDS, separated by SDS-PAGE, and visualized by fluorography. The arrow indicates the position of GAP-43. Note that antibodies 6-2G3 and 9-1D1 fail to precipitate the unmodified protein. $C$, Recognition of charged isoforms of GAP-43 resolved by isoelectric focusing. Proteins from a growth cone membrane preparation were resolved by high-resolution isoelectric focusing (nominal pH range, 4-6), blotted to nitrocellulose, and probed with the indicated antibodies. Arrows indicated four charged isoforms of GAP-43 resolved under these conditions; previous studies suggest that the most basic isoform (lowest band) comigrates with the primary translation product with or without covalently linked fatty acid (Skene and Virág, 1989), while the more acidic forms represent later posttranslational modifications of GAP-43, including phosphorylations (Zwiers et al., 1985; Skene and Virág, 1989; Meiri et al., 1991). Notice that antibodies 6-2G3 and 9-1DI fail to recognize the most basic isoform. Antibody dilutions are the same as in $A$. $D$, Differential affinities for GAP-43 isoforms separated by high-voltage SDS-PAGE. Proteins from a growth cone membrane preparation were solubilized in precipitation buffer and incubated with each of the indicated antibodies prebound to agarose beads as in $B$, except that incubation was carried out under conditions of antigen excess (approximately $100 \mu \mathrm{g}$ of growth cone membrane protein per reaction). Immune complexes were collected and solubilized as in $B$, and then separated by SDS-PAGE under low-load, high-voltage conditions that improve resolution of some modified forms of GAP-43 (Patterson and Skene, 1991). Under these conditions, the various forms of GAP-43 present in the membrane sample should compete for antibody binding, revealing the relative affinities of each antibody for different forms of GAP-43. The precipitated GAP-43 was visualized on Western blots by probing with antibody 9-1E12 (small arrows). Note that under these conditions, antibodies 8 - $1 G 8$ and 8 - $2 F 9$ preferentially precipitate a slowly migrating species of GAP-43 (upper small arrow) that appears as a relatively minor "trail" behind the major GAP-43 band in the pool of total growth cone membrane proteins. Antibodies 6-2G3,9-1D1 (charge selective), and 9-1E12 (charge insensitive) precipitate protein species that migrate with the major GAP-43 band (lower small arrow). Heavy staining at the top of each lane reflects binding of the anti-lgG secondary antibody to the IgGs from the original immunoprecipitates (open arrow).
} 
experiments the dorsal column axons were not injured, and they were not confronted with an environment conducive to growth. The central delivery and accumulation of GAP-43, therefore, is strongly correlated with the potential of these axons for effective regeneration, but not necessarily with overt elongation, which depends both on the axons' competence for growth and on local cues in the environment that can elicit or inhibit outgrowth from such competent axons.

Examination of GAP-43 accumulation in the dorsal columns at several times after peripheral nerve injury has allowed us to follow the series of events leading up to the differences between crush and resection lesions at 8 weeks postlesion. Although crush lesions are as effective as resection lesions in causing the initial induction and central transport of GAP-43, increased levels of GAP-43 persist for a much longer time as a consequence of resection lesions. Crush lesions permit effective regeneration of the peripheral axons within approximately 4 weeks (Warszawski et al., 1975; Devor et al., 1979), while resection lesions strongly inhibit regeneration and the reinnervation of target tissues. The persistence of GAP-43 in all parts of the DRG neurons at long times after resection lesions therefore is consistent with repression of GAP-43 expression by a retrograde signal initiated by axon-target contact (Baizer and Fishman, 1987; Bisby, 1988). In a previous study, Richardson and Verge (1986) concluded that the metabolic changes underlying the enhanced regenerative potential of dorsal column axons were controlled by chronic repressive cues originating along the peripheral axons of DRG neurons. Their hypothesis was based on the assumption that the presence of regenerating DRG axons in peripheral nerve grafts 2-3 months after peripheral nerve lesions reflected the initial regenerative potential of the DRG neurons. Tu the extent that GAP-43 can serve as a marker for a broader regenerative response, however, our observations raise the possibility that differences in the regenerative success of the dorsal column axons-assayed 2 months or more after peripheral crush or resection injury-may reflect differences in the persistence of regenerative changes in DRG neurons rather than in their initial induction. Under this interpretation, dorsal column axons in the peripheral nerve grafting experiments may have begun to regenerate following crush lesions, only to stop growing or even retract after reestablishment of peripheral target contact by peripheral axons.

\section{Delayed accumulation in long spinal segments of $D R G$ axon}

Our evidence shows that GAP-43, once induced in DRG neuronal somata, can be transported many centimeters through axon shafts lying within a CNS environment. However, in the cervical dorsal columns, GAP-43 accumulation becomes apparent only after a delay of more than 1 week. This contrasts with the rapid accumulation of GAP-43 immunoreactivity in all extraspinal (PNS) tissues. In peripherally projecting axons of the sciatic nerve, in the ganglia, and in the dorsal roots, increased accumulation of GAP-43 was detected within $2 \mathrm{~d}$ after a lesion. Subsequently, GAP-43 is deposited most heavily near the distal ends of the regenerating axons, consistent with its rapid accumulation within growth cones and slower deposition along intervening axon shafts in cultured neurons (Meiri et al., 1988; Goslin et al., 1990). Thus, GAP-43 accumulation in these extraspinal portions of DRG neurons closely follows induction of the mRNA in DRG cell bodies (Basi and Skene, 1988; Hoffman, 1989; Van der Zee et al., 1989).

It is unlikely, however, that the delayed accumulation of GAP-
43 immunoreactivity in dorsal column axons, beginning 2-3 weeks after injury, reflects a late induction of GAP-43 mRNA or protein synthesis in the subpopulation of DRG neurons projecting to the cervical dorsal columns. In situ hybridization studies (Verge et al., 1990) show that virtually all neurons in the lumbar DRG have induced high levels of GAP-43 mRNA by 1 week after sciatic nerve injury. Our own counts of GAP43-immunoreactive cell bodies also are consistent with elevated expression and accumulation of GAP-43 in all axotomized DRG neurons within 1 week of injury, and show no subsequent increase in the numbers of DRG neurons expressing GAP-43 (Fig. 3). Thus, delayed accumulation of GAP-43 in dorsal column axons, lagging more than 1 week behind the induction of GAP43 mRNA and contrasting with the rapid accumulation in extraspinal axon segments, indicales that accumulation of GAP43 can be strongly modulated by late posttranslational events subsequent to its induction, synthesis, and initial routing into axons.

GAP-43 might fail to accumulate more rapidly in the cervical dorsal column axons either because it fails to reach the distal segments of these CNS axons, or because newly synthesized GAP-43 delivered to the distal axons fails to be deposited and stabilized there. GAP-43 might fail to reach distal axon segments if the supply of ncwly synthesized protein were exhausted by preferential routing to more proximal collaterals or preempted by deposition in proximal segments of the ascending axon shafts. The latter possibility would contrast with the more common finding of initial deposition and accumulation of GAP43 in distal axon segments (Skene and Willard, 1981c; Goslin et al., 1990), followed by accumulation in progressively more proximal regions of the axon shafts (Meiri et al., 1988; Goslin et al., 1990).

Alternatively, if newly synthesized GAP-43 is transported rapidly to the distal segments of ascending spinal axons, its retarded accumulation there might reflect local posttranslational control of GAP-43 deposition and stabilization. We have previously suggested that attachment of GAP-43 to axonal membranes may be regulated through cycles of fatty acylation and deacylation at the protein's amino terminus (Skene and Virág, 1989), a domain of the protein essential for membranc attachment (Zuber et al., 1989). Others have suggested that GAP-43 can accumulate selectively in the submembranous cytoskeleton at sites of membrane adhesion (Meiri and Gordon-Weeks, 1990; see also Goslin et al., 1990). The proposed cytoskeletal binding site at the carboxy terminus of GAP-43 (LaBate and Skene, 1989) also contains potential sites for phosphorylation (Pisano et al., 1988). Thus, both the membrane- and proposed cytoskeletal-attachment sites of GAP-43 are subject to local posttranslational regulation. Regional variations in accumulation of the protein suggest that these or other posttranslational mechanisms controlling the deposition and stabilization of GAP-43 are sensitive to local signals that differ among axonal domains. The locally regulated accumulation of GAP-43 is reminiscent of several recent reports of axonal membrane proteins deposited preferentially in separate domains of developing or regenerating axons distinguished by their growth states and/or their local environments (Bastiani et al., 1987; Dodd et al., 1988; Jessell, 1988; Bastmeyer et al., 1990). All of these previous examples have been cell-adhesion molecules exposed on the surfaces of axons, but they have included both transmembrane proteins (Dodd et al., 1988; Bastmeyer et al., 1990) and proteins linked peripherally to the external surfaces of axonal membranes 
(Hortsch and Goodman, 1990). GAP-43 adds to this list a protein normally disposed on the cytoplasmic surface of axonal membranes.

The distal portions of dorsal column axons, where GAP-43 accumulation is very slow, differ in at least two important ways from the distal segments of peripherally projecting branches of DRG axon, where GAP-43 accumulates most rapidly after its initial induction. Unlike the peripheral branches, the dorsal column axons in our experiments were not actively elongating, and they lie in a mature CNS white matter environment. These differences raise the possibility that local deposition and stabilization of GAP-43 is promoted by signals generated during active growth cone extension in a favorable environment, and or impeded by environmental cues generated along axon shifts within mature CNS white matter. Within the regenerating peripheral axon branches, preferential accumulation of GAP-43 in the vicinity of emerging growth cones suggests that local signals generated in the course of growth cone activation may indeed enhance GAP-43 deposition and accumulation. However, GAP-43 also accumulates much more readily in DRG cell bodies, along nerve segments proximal to an injury site, and along the dorsal roots than along dorsal column axons. These differences suggest that GAP-43 deposition and turnover are also responsive to local cues that differ between axon shafts lying in mature CNS and PNS white matter. Although we cannot yet define the local signals responsible for differential accumulation of GAP-43 in different axonal environments, our data show that local deposition and stabilization of GAP-43 can be modulated at the posttranslational level by factors distinct from those regulating induction of the mRNA and protein synthesis in ncuron ccll bodics.

\section{Posttranslational modifications and selective antibody recognition in terminal zones}

In an earlier report, in which a sheep antiserum against GAP43 was used, little or no GAP-43 immunoreactivity was found in the dorsal horns of normal adult rats, but increased accumulation of GAP-43, presumed to derive from DRG neurons, in the ipsilateral dorsal horn was reported (Woolf et al., 1990). Because we have characterized the specificity of four antibodies that give comparable results, and one that does not, we are able to offer the following explanation for the disparate results. Antibody $9-1 \mathrm{E} 12$ recognizes an epitope on GAP-43 that is present on all known forms of the protein, while antibodies $6-2 \mathrm{G} 3$, 8-1G8, 8-2F9, and 9-1D1 each recognize variable epitopes, present on only some forms of the protein (Fig. 9). Two of these antibodies (6-2G3 and 9-1D1) fail to recognize newly translated GAP-43 that has not undergone posttranslational modification (Fig. 9). Two others (8-1G8 and 8-2F9) can recognize both unmodified GAP-43 and charge-modified forms of GAP-43 under conditions of antibody excess, but under conditions of limited antibody they reveal much higher affinity for a quantitatively minor form of the protein (Fig. $9 D$ ). In contrast, antibody 9-1E12 recognizes the unmodified primary translation product of GAP-43 (Fig. 9B) and all known modified forms of the protein, including fatty acylated and phosphorylated isoforms (Skene and Virag, 1989; see also Fig. 2) and the species of GAP-43 recognized preferentially by each of our other antibodies (Fig. $9 D$ ). Thus, the labeling pattern seen with 9-1E12 should correspond closely to the total distribution of GAP-43, while the labeling patterns seen with the four isoform-selective monoclo- nal antibodies are likely to reflect the distribution of specific modified forms of the protein. Using an antibody specific for GAP-43 that has been phosphorylated by protein kinase C, Meiri et al. (1991) have documented another case in which the distribution of a particular modified form of GAP-43 is spatially and temporally distinct from the expression and distribution of total GAP-43, revealed by a less selective antibody.

The monoclonal antibodies used here were initially selected without reference to their recognition of modified forms of GAP43 , but subsequent characterization showed that $80 \%$ of these antibodies recognize epitopes sensitive to posttranslational modification. Thus, it would not be surprising to find that some polyclonal antisera are dominated by antibodies that recognize a subset of the isoforms of GAP-43. From our observations with antibody 9-1E12, we conclude that the normal dorsal horn does contain substantial amounts of GAP-43. The results with our other antibodies, however, indicate that sciatic nerve lesions increase the proportion of GAP-43 molecules bearing certain posttranslational modification(s) in the dorsal horn of the spinal cord. Our data do not allow us to distinguish whether the GAP43 present in normal dorsal horns represents accumulation in the axons and terminals of those DRG neurons that express detectable levels of GAP-43 in unoperated rats (Fig. 3), or whether it arises from other sources, such as indigenous neurons and glial cells or bulbospinal neurons projecting to the dorsal horn (Basbaum et al., 1978). Heavy staining of Lissauer's tract suggests that at least some of the GAP-43 in the normal dorsal horn arises from DRG cells or other afferent neurons. The increase in modified forms of GAP-43 in the dorsal horn after sciatic nerve injury may reflect posttranslational modification of preexisting GAP-43, or the induction and subscquent modification of GAP-43 in cells distinct from those that produce the GAP-43 present in the normal dorsal horn.

\section{Summary}

The present findings with antibody 9-1E12 indicate that the amount of GAP-43 present in an axon or axon terminal can be regulated both at the level of mRNA production and protein synthesis and at the level of posttranslational mechanisms controlling local deposition and stability of the protein. Posttranslational control of GAP-43 accumulation appears to be regulated in response to environmental cues that differ between PNS and CNS white matter tracts. Although local factors along a mature CNS pathway can substantially modulate the timing and distribution of GAP-43 accumulation, they do not prevent the eventual accumulation of GAP-43, even in long spinal axons, when cells continue to synthesize high levels of the protein for a period of several weeks. In long DRG axons ascending the spinal cord, the accumulation of GAP-43 is closely correlated with functional changes that confer on these axons competence to regenerate in response to an appropriate growth environment. Investigations with a series of additional antibodies indicate that many antibodies generated against GAP-43 do not accurately reflect patterns of GAP-43 expression, but instead reveal additional posttranslational modifications that can vary in response to regulatory cues separate from those that control GAP43 synthesis and deposition.

\section{References}

Baizer L, Fishman MC (1987) Recognition of specific targets by cultured dorsal root ganglion neurons. J Neurosci 7:2305-2311. 
Basbaum AI, Clanton CH, Fields HL (1978) Three bulbospinal pathways from the rostral medulla of the cat: an autoradiographic study of pain modulating systems. J Comp Neurol 178:209-224.

Basi GS, Skene JHP (1988) Regulation of GAP-43 gene expression during axonal regeneration in sensory neurons. Soc Neurosci Abstr 14:803.

Basi GS, Jacobson RD, Virag I, Schilling J, Skene JHP (1987) Primary structure and transcriptional regulation of GAP-43, a protein associated with nerve growth. Cell 49:785-791.

Bastiani MJ, Harrelson AL, Snow PM, Goodman CS (1987) Expression of fasciclin I and II glycoproteins on subsets of axon pathways during neuronal development in the grasshopper. Cell 48:745-755.

Bastmeyer M, Schlosshauer B, Stuermer CA (1990) The spatiotemporal distribution of N-CAM in the retinotectal pathway of adult goldfish detected by the monoclonal antibody D3. Development 108: 299-311.

Benfy M, Aguayo AJ (1982) Extensive elongation of axons from rat brain into peripheral nerve grafts. Nature 296:150-152.

Bennett FC, Yeoman LC (1983) An improved procedure for the 'dot immunobinding' analysis of hybridoma supernatants. J Immunol Methods 6:201-207.

Bisby MA (1981) Axonal transport in the central axon of sensory neurons during regeneration of their peripheral axon. Neurosci Lett 21:7-11.

Bisby MA (1988) Dependence of GAP43 (B50, F1) transport on axonal regeneration in rat dorsal root ganglion neurons. Brain Res 458:157161.

Bisby MA, Tetzlaff W, Alexander S (1990) Axotomized corticospinal neurons do not increase tubulin and GAP43 mRNA expression. Soc Neurosci Abstr 16:339.

David S, Aguayo AJ (1981) Axonal elongation into peripheral nervous system "bridges" after central nervous system injury in adult rats. Science 214:931-933.

Devor M, Schonfeld D, Seltzer Z, Wall PD (1979) Two modes of cutaneous reinnervation following peripheral nerve injury. J Comp Neurol 185:211-220.

Dodd J, Morton SB, Karagogeos D, Yamamoto M, Jessell TM (1988) Spatial regulation of axonal glycoprotein expression on subsets of embryonic spinal neurons. Neuron 1:105-116.

Doster SK, Lozano AM, Aguayo AJ, Willard M (1991) Expression of the growth-associated protein GAP-43 in adult rat retinal ganglion cells following axon injury. Neuron 6:1-13.

Friedman B, Aguayo AJ (1985) Injured neurons in the olfactory bulb of the adult rat grow axons along grafts of peripheral nerves. J Neurosci 5:1616-1625.

Galfrè G, Milstein C (1981) Preparation of monoclonal antibodies: strategies and procedures. Methods Enzymol 73:3-46.

Goslin K, Schreyer DJ, Skene JHP, Banker G (1990) Changes in the distribution of GAP-43 during the development of neuronal polarity. J Neurosci 10:588-602.

Himes BT, Tessler A (1989) Death of some dorsal root ganglion neurons and plasticity of others following sciatic nerve section in adult and neonatal rats. J Comp Neurol 284:215-230.

Hoffman PH (1989) Expression of GAP-43, a rapidly transportcd growth-associated protein, and class II beta tubulin, a slowly transported cytoskeletal protein, are coordinated in regenerating neurons. J Neurosci 9:893-897.

Hortsch M, Goodman CS (1990) Drosophila fasciclin I, a neural cell adhesion molecule, has a phosphatidylinositol lipid membrane anchor that is developmentally regulated. J Biol Chem 265:15104-15109.

Jessell TM (1988) Adhesion molecules and the hierarchy of neural development. Neuron 1:3-13.

Kalil K, Skene JHP (1986) Elevated synthesis of an axonally transported protein correlates with axon outgrowth in normal and injured pyramidal tracts. J Neurosci 6:2563-2570.

Köhler G, Milstein C (1975) Continuous cultures of fused cells secreting antibodies of predefined specificity. Nature 256:495-497.

LaBate ME, Skenc JHP (1989) Sclective conservation of GAP-43 structure in vertebrate evolution. Neuron 3:299-310.

Laemmli UK (1970) Cleavage of structural proteins during the assembly of the head of bacteriophage T4. Nature 227:680-685.

Lorenz T, Willard M (1978) Subcellular fractionation of intra-axonally transported polypeptides in the rabbit visual system. Proc Natl Acad Sci USA 75:505-509.

Meiri KF, Gordon-Weeks PR (1990) GAP-43 in growth cones is as- sociated with areas of membrane that are tightly bound to substrate and is a component of a membrane skeleton subcellular fraction. $\mathbf{J}$ Neurosci 10:256-266.

Meiri KF, Pfenninger KH, Willard MB (1986) Growth-associated protein, GAP-43, a polypeptide that is induced when neurons extend axons, is a component of growth cones and corresponds to pp46, a major polypeptide of a subcellular fraction enriched in growth cones. Proc Natl Acad Sci USA 83:3537-3541.

Meiri KF, Willard M, Johnson MI (1988) Distribution and phosphorylation of the growth associated protein GAP-43 in regenerating sympathetic neurons in culture. J Neurosci 8:3537-3542.

Meiri KF, Bickerstaff LE, Schwob JE (1991) Monoclonal antibodies show that kinase $C$ phosphorylation of GAP-43 during axogenesis is both spatially and temporally restricted in vivo. J Cell Biol 112:9911005.

Morrisey JH (1981) Silver stain for proteins in polyacrylamide gels: a modified procedure with enhanced uniform sensitivity. Anal Biochem 117:307-310.

Oblinger MM, Lasek RJ (1988) Axotomy-induced alterations in the synthesis and transport of neurofilaments and microtubules in dorsal root ganglion cells. J Neurosci 8:1747-1758.

Patterson SI, Skene JHP (1991) Two forms of GAP-43 distinguished by migration on SDS-PAGE correlate with the palmitoylated and non-palmitoylated isoforms. Soc Neurosci Abstr 17:1311.

Pisano MR, Hegazy MG, Reimann EM, Dokas L (1988) Phosphorylation of protein $\mathrm{B}-50(\mathrm{GAP}-43)$ from adult rat brain cortex by casein kinase II. Biochem Biophys Res Commun 155:1207-1212.

Pfenninger KH, Ellis L, Johnson MP, Friedman LB, Somlo F (1983) Nerve growth cones isolated from fetal rat brain: subcellular fractionation and characterization. Cell 35:573-584.

Radola BJ (1984) High-resolution preparative isoelectric focusing. Methods Enzymol 104:256-275.

Redshaw JD, Bisby MA (1984) Fast axonal transport in central nervous system and peripheral nervous system axons following axotomy. J Neurobiol 15:109-118.

Reh T, Redshaw JD, Bisby MA (1987) Axons of the pyramidal tract do not increase their transport of growth-associated proteins after axotomy. Mol Brain Res 2:1-6.

Richardson PM, Issa VMK (1984) Peripheral injury enhances central regeneration of primary sensory neurons. Nature 309:791-793.

Richardson PM, Verge VMK (1986) The induction of a regenerative propensity in sensory neurons following peripheral axonal injury. $\mathrm{J}$ Neurocytol 15:585-594.

Richardson PM, McGuiness UM, Aguayo AJ (1982) Peripheral nerve autografts to the rat spinal cord: studies with axonal tracing methods. Brain Res 237:147-162.

Richardson PM, Issa VMK, Aguayo AJ (1984) Regeneration of long spinal axons in the rat. J Neurocytol 13:165-182.

Skene JHP (1989) Axonal growth-associated proteins. Annu Rev Neurosci 12:127-156.

Skene JHP, Virág I (1989) Posttranslational membrane attachment and dynamic fatty acylation of a neuronal growth cone protein, GAP43. J Cell Biol 108:613-624.

Skcnc JHP, Willard M (1981a) Changes in axonally transported proteins during axon regeneration in toad retinal ganglion cells. J Cell Biol 89:86-95.

Skene JHP, Willard M (1981b) Axonally transported proteins associated with axon growth in rabbit central and peripheral nervous systems. J Cell Biol 89:96-103.

Skene JHP, Willard M (1981c) Characteristics of growth-associated polypeptides in regenerating toad retinal ganglion cell axons. J Neurosci 1:419-426.

Skene JHP, Jacobson RD, Snipes GJ, McGuire CB, Norden JJ, Freeman JA (1986) A protein induced during nerve growth (GAP-43) is a major component of growth-cone membranes. Science 233:783-786.

Tetzlaff W, Zwiers H, Lederis K, Cassar L, Bisby MA (1989) Axonal transport and localization of B-50/GAP-43-like immunoreactivity in regencrating sciatic and facial nerves of the rat. J Neurosci 9:13031313.

Van der Zee CEEM, Nielander HB, Vos JP, Lopes da Silva S, Verhaagen J, Oestreicher AB, Schrama LH, Schotman P, Gispen WH (1989) Expression of growth-associated protein B-50 (GAP-43) in dorsal root ganglia and sciatic nerve during regenerative sprouting. J Neurosci 9: $3505-3512$.

Verge VMK, Tetzlaff W, Richardson PM, Bisby MA (1990) Corre- 
lation between GAP43 and nerve growth factor receptors in rat sensory neurons. J Neurosci 10:926-934.

Vesterberg O (1972) Isoelectric focusing of proteins in polyacrylamide gels. Biochim Biophys Acta 257:11-19.

Vidal-Sanz M, Bray GM, Villegas-Pérez MP, Thanos S, Aguayo AJ (1987) Axonal regeneration and synapse formation in the superior colliculus by retinal ganglion cells in the adult rat. J Neurosci 7:2894 2909.

Warszawski M, Telerman-Toppet N, Durdu J, Graff GLA, Coërs C (1975) The early stages of neuromuscular regeneration after crushing the sciatic nerve in the rat. Electrophysiological and histological study. J Neurol Sci 24:21-32.

Willard MB, Cowan WM, Vagelos PR (1974) The polypeptide com- position of intra-axonally transported proteins: evidence for four transport velocities. Proc Natl Acad Sci USA 71:2183-2187.

Woolf CJ, Reynolds ML, Molander C, O'Brian D, Lindsay RM, Benowitz LI (1990) The growth-associated protein GAP-43 appears in dorsal root ganglion cells and in the dorsal horn of the rat spinal cord following peripheral nerve injury. Neuroscience 34:465-478.

Zuber MX, Stittmayer SM, Fishman MC (1989) A membrane targetting signal in the amino terminus of the neuronal protein GAP43. Nature 341:345-348.

Zwiers H, Verhaagen J, van Dongen CJ, de Graan PNE, Gispen WH (1985) Resolution of rat brain synaptic phosphoprotein B-50 into multiple forms by two-dimensional electrophoresis: evidence for multisite phosphorylation. J Neurochem 44:1083-1090. 